Environment Conservation Journal 14(3)137-141, 2013

ISSN 0972-3099 (Print) 2278-5124 (Online)

Abstracted and Indexed

\title{
Comparative analysis of minerals found in male and female hair of different age groups
}

\author{
Poonam Sherry and Ashok Kumar $\bowtie$
}

Received: 15.02.2013

Revised:27.05.2013

Accepted: 01.7.2013

\begin{abstract}
In present scenario of pollution and UV radiation, it is our urgent requirement to determine the baseline levels of mineral constituents in human beings. It causes major health problems in general population. This paper deals with quantitative determination of minerals in human hair. Biological samples were collected for environmental quality investigation randomly from male and female subjects of selected group aged from 5 year to 60 year of different social status. Sample collection and preparation were carried out using standard procedures. Levels of minerals (calcium, magnesium and phosphorus) were estimated using analytical methods. The levels of all the minerals studied and mean concentration of female hair were significantly higher. Significant levels of minerals in human hair samples indicate the type of exposure of male and female subjects
\end{abstract}

Keywords: Calcium, exoskeleton, magnesium, minerals, phosphorus, scalp hair

\section{Introduction}

The air is full of deadly elements and harmful gases along with dust particles. Various gases present in air emitted from the vehicles and through the chimneys of factories affect the health of people in one or the other way and lead to several diseases. Sulphur di oxide and nitrogen oxide affect skin, hair, lungs, nervous system, respiratory system and decreases immunity towards various diseases (Chaudhary, 2003). The determination of trace elements in hair has been the subject of continuous interest in the biomedical and environmental sciences (Arnold and Sachs, 1994). Hair can be considered to be an excretory product, the trace element contents of which reflect mineral metabolism in the body. However, their concentrations bear little relation to the levels in other tissues (Kaluza et al.2001). It should be noted that human hair is an attractive biological material because of the simplicity of sampling, transport and handling as well as providing information about concentrations of some trace elements that are considerably more concentrated in hair than other biological materials, which makes analysis easier (Zhunk and Kist, 1995). Among many human

\section{Author's Address}

School of Chemical Sciences, Department of Chemistry, St. John's College, Agra (India)

Email: drashokchemsjc@gmail.com tissue, hair and nails are widely used as biomarkers of environmental burden of toxic metals due to ease of sample collection, transportation, storage, and preparation for analysis (Nowak, 1993; Chaudhry et al. 1995; Agahian et al.1990; Schegel-zawadzka, 1992; Das et al.1995). The importance of these examinations is attested by the fact that there are several trace elements in the human body that are important in biochemical processes (Abdulrahmani et al. 2012). Researches have been carried out with the aim of correlating various diseases (Wang et al. 1995). An excess or absence of these essential trace elements causes serious problems in the physiology of the body (Dombovári and Papp, 1998) (Dombovári et al. 1999).Human hair and nails were analysed with the same analytical technique as biological samples for bio monitoring body burden of elements and occupational exposure to metal pollution (Wilhelm et al.1994; Chen et al. 1999; Egeland et al.1999; Hira et al. 2004). The bioaccumulation of heavy metals in human hair and nails is rather a complex process and influenced by several factors like environmental quality, age, sex (Chakraborti et al.1998; Steinmaus et al. 2000; Aharoni and Tesler, 1992).The Central Pollution Control Board, Faridabad carried out Comprehensive Environmental Pollution Index Assessment (CEPI) study in association with Indian 
Institute of Technology, Delhi for 88 industrial clusters in the country. Based on the study, 43 industrial clusters have been declared as critically polluted having CEPI of more than 70 and the District Faridabad has been listed at the $18^{\text {th }}$ place. Pollution and UV exposure cause major health problems in general population. This paper deals with quantitative determination of minerals as calcium $(\mathrm{Ca})$, magnesium $(\mathrm{Mg})$ and phosphorus $(\mathrm{P})$ of male and female hair in different age groups.

\section{Material and Methods}

Samples were collected from the people working in offices and factories, school and college going students, road side and residential area. The criterion of collection was based on age groups i.e. (5-10 year), (15-20 year), (25-30 year), (35-40 year), (45-50 year) and (55-60 year). Five samples of each category of male and female subjects were taken for the analysis. For subsequent analysis each of samples was sealed in plastic cover till it was washed, dried, digested and converted into solution. Samples were washed thoroughly in separate beakers by several changes of distill water and dried in air at room temperature for 36 hours. Whole samples of each group taken together and grounded separately in an electrical grinder. Considering the importance of quality assurance of analytical technique as reported (Subramanian and Sukumar, 1988). Moisture was determined by keeping $1 \mathrm{gm}$. of the air dried material in an aluminum cup in an electric oven at $100^{\circ} \mathrm{C}$ for 24 hours and then weighing the oven dried material. Ash content was determined by keeping $1 \mathrm{gm}$. of the material in a muffle furnace at $900^{\circ} \mathrm{C}$ till the weight of the ash was constant. Estimation of $\mathrm{Ca}$, $\mathrm{Mg}$ and $\mathrm{P}$ was done by analytical method. Meticulous care was taken to avoid external contamination of samples during analytical procedure. The study was carried out for the time period of one year from January 2009- February 2010.

\section{Process}

For estimation of $\mathrm{Ca}$, about $100 \mathrm{mg}$ of ash was dissolved in the minimum quantity of $\mathrm{HCI}$ and $\mathrm{Ca}$ was precipitated as calcium oxalate and determined volumetrically. Using standard $\mathrm{KMnO}_{4}$ solution after liberating free oxalic acid by dissolving the precipitate in dil. $\mathrm{H}_{2} \mathrm{SO}_{4}$. For estimation of $\mathrm{Mg}$, about $500 \mathrm{mg}$ of ash was taken which was determined calorimetrically after removing calcium as calcium sulphate precipitate using the reagent Erichrome black-T (Snell and Snell, 1967).For estimation of $\mathrm{P}$, about $20 \mathrm{mg}$ of ash was dissolved in the minimum quantity of $\mathrm{HNO}_{3}$ and phosphorus was precipitated as canary yellow ammonium phosphomolybdate then determined by alkali metric method (Cumming and Kay revised 1956).

\section{Results and Discussion}

The Mean concentration of male and female hair in different age groups are tabulated in table 1 and 2 and figure 1 and 2.Mineral analysis of human hair in different age groups indicated that $\mathrm{Ca}, \mathrm{Mg}$ and $\mathrm{P}$ are the principal salts occurring in exoskeleton tissues of human beings. The concentration of $\mathrm{Ca}$ has higher range value than $\mathrm{Mg}$ and $\mathrm{P}$. $\mathrm{Ca}$ is an essential element that is involved in many physiological functions. $\mathrm{Ca}$ might result in malfunction of the parathyroid gland. The variation in values is due to food habits and probably to the exposure of various substances causing high variation of mineral levels. In hair, ratio of $\mathrm{Ca}$ and $\mathrm{Mg}$ was approximately 8:1. Females have significantly higher $\mathrm{Ca}$ levels than males. After age of 10 year level becomes quite stable. Females have higher Mg levels than males. Detergent washing reduced the element concentration more than the organic solvent washing (Harrison and Tyree, 1971). However, for heavy metals, washing procedure does not essentially influence their concentration because of the strong complex with the disulphide groups in the keratin proteins (Chen et al., 1999). Nail samples were observed to accumulate higher concentrations of heavy metals when compared to hair samples, such differences might be attributed to the incorporation of elements into the keratin structure of hair which takes place by binding to the sulfahydryl groups that are present in the follicular protein. In this regard, the detergents such as soap, shampoos, hair pomades, lotions, hair bleaches and dyes actually compete with the complexing ability of these reactive sites, thus leading to a significant leaching of elements from the shaft bulk (Buchancoca et al., 1993). Iron welders showed higher concentrations of heavy metals when compared to liquor users and non-liquor users, such variation might be attributed to the fact that the major sources of heavy metals in occupational 138

Environment Conservation Journal 
Comparative analysis of minerals found

Table 1: Mean concentration of male hair in different age groups (values are expressed in mg./kg.)

\begin{tabular}{|l|l|l|l|l|l|l|}
\hline \multirow{2}{*}{\multicolumn{1}{c|}{ Minerals }} & \multicolumn{6}{|c|}{ Age Groups (in Year) } \\
\cline { 2 - 8 } & $5-10$ & $15-20$ & $25-30$ & $35-40$ & $45-50$ & $55-60$ \\
\hline $\mathrm{Ca}$ & 551 & 902 & 1147 & 869 & 1001 & 923 \\
\hline $\mathrm{Mg}$ & 113 & 125 & 170 & 152 & 127 & 114 \\
\hline $\mathrm{P}$ & 195.4 & 200.4 & 230.03 & 211.5 & 194 & 171 \\
\hline
\end{tabular}
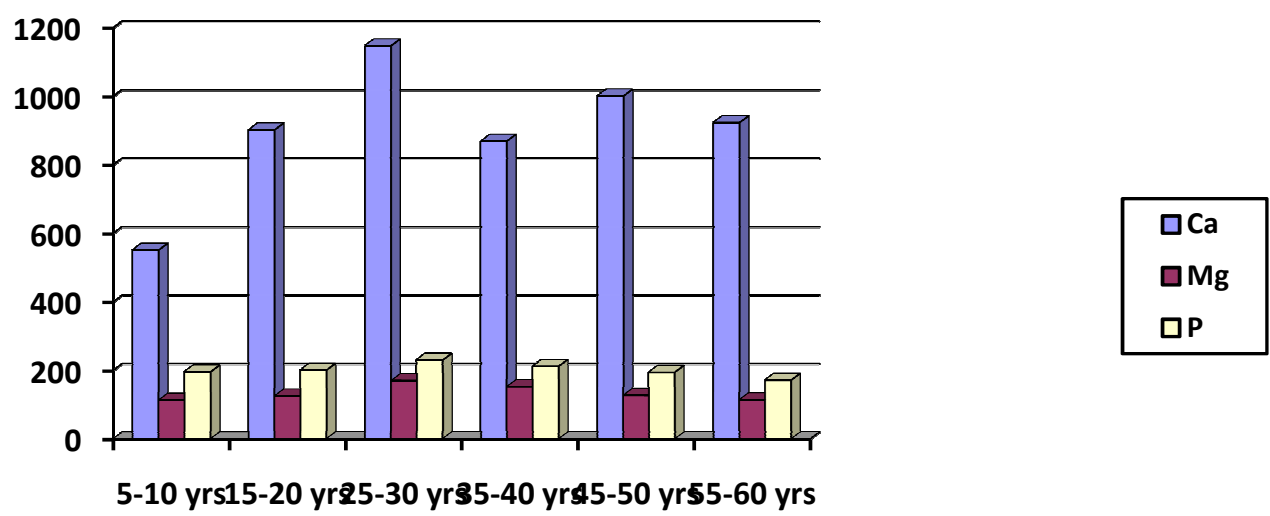

Figure 1: Graphical representation of minerals in male hair in different age group

Table2: Mean concentration of female hair in different age groups (values are expressed in mg./kg.)

\begin{tabular}{|l|l|l|l|l|l|l|}
\hline \multirow{2}{*}{ Minerals } & \multicolumn{7}{|c|}{ Age Groups (in Year) } \\
\cline { 2 - 7 } & $5-10$ & $15-20$ & $25-30$ & $35-40$ & $45-50$ & $55-60$ \\
\hline $\mathrm{Ca}$ & 561 & 1966 & 1924 & 1731 & 1668 & 1660 \\
\hline $\mathrm{Mg}$ & 113 & 224 & 216 & 194 & 180 & 175 \\
\hline $\mathrm{P}$ & 197.3 & 210.4 & 222.3 & 215.4 & 207.3 & 201.5 \\
\hline
\end{tabular}

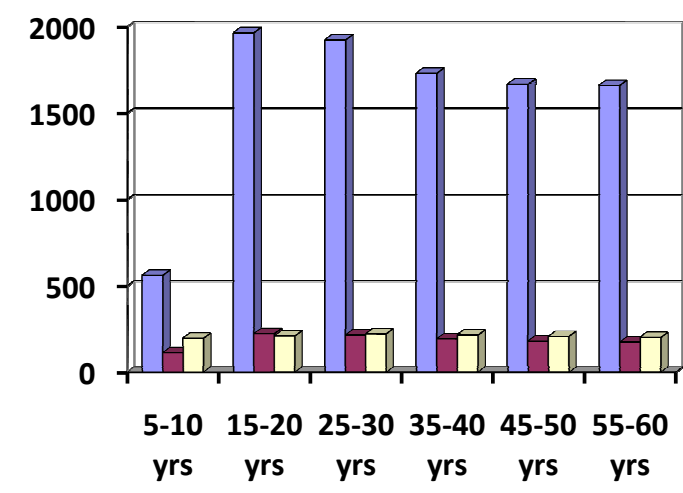

Figure 2: Graphical representation of minerals in female hair in different age group 
exposed worker includes batteries, alloys and electroplating metal parts among others (Buchancoca et al., 1993).Ca levels of male hair increases upto certain age group. Mean concentration of $\mathrm{Mg}$ level of male hair fluctuates with age. Level of $\mathrm{P}$ in male and female hair increases upto certain age than falls gradually. Ca level of male and female hair was higher in middle age group (35-40 years) than in older age group (55-60 years) and younger age group (5-10 years). $\mathrm{Mg}$ level of male and female hair was higher in middle age group than younger age group and older age group. P level of male hair was higher in middle age group and gradually falls afterwards. $\mathrm{P}$ level of female hair is highest in middle age group than older age group and younger age group. The data in Table I and II clearly supports the hypothesis that at each age level, the female mean concentration level was significantly higher than the male. Female calcium, magnesium and phosphorus levels were consistently higher at all age levels. Trace elements accumulate in the body over given periods of time, therefore, they reflect the biomedical and environmental history of the body as well as long term metabolic changes (Suhonen and Dawber, 1999) (D'Ili o et al, 2000).It is concluded that the effects of air pollution or harmful chemicals on human are in many cases life- threatening, and can be fatal. WHO statistics report (1994) that over 2 million people leads to the fatalities and attributed to air pollution. Consistent exposure to pollutants leads to the development of a large number of diseases. Human hair is the most exposed part of the body. It can be very easy to predict the future health problems through hair analysis. Increased or decreased mean concentrations of minerals would be helping in estimation of forthcoming diseases or health complications. Analysis of minerals in male and female subject show requirement of nutrient and energy change throughout life cycle. Diet we eat matters a lot in constitution of our exoskeleton tissues. The mean concentration was maximum at middle age group (25-30 year) because of diet and exposure. Females have excess $\mathrm{Ca}$ in their tissues in comparison of $\mathrm{Mg}$. Eating too much sugar is one of the major reason for $\mathrm{Ca}$ imbalance.

\section{Acknowledgement}

Authors are thankful to local residents of Faridabad for giving hair samples for the study.

\section{References}

Abdulrahman F I, Akan J C, Chellube Z M and Waziri M, 2012. Levels of Heavy Metals in Human Hair and Nail Samples from Maiduguri Metropolis, Borno State, Nigeria. World Environment, 2 (4): 81-89

Agahian B, Lee J S, Nelson J H and Johns R E, 1990. Arsenic levels in fingernails as a biological indicator of exposure to arsenic. Am Ind Hyg Assoc J, 51 (12): 646-51

Aharoni A, Tesler B, Paltieli Y, Tal J, Dori Z and Sharf M,1992. Hair chromium content of women 1992. Hair chromium content of women with gestational diabetes compared with nondiabetic pregnant women. American Journal of Clinical Nutrition, 55 (1): 104-7

Arnold W and Sachs H, 1994. Hair analysis for medicaments the best proof for a drug career, Freseniu. Journal of Analytical Chemistry, 348: 484-489

Buchancoca J, Vrlik M, Knizkova M, Mesco D and Holko, L 1993. Levels of selected element (Fe, As, Cd, Pb, Zn, Mn) in biological samples from ferrochromium workers. Bratisl Lek. Listy, Canadian Journal of Pure and Applied sciences, 94: 73-387

Chakraborti D, Samanta G, Mandal B K, Chowdhury T R, Chanda C R, Biswas B K, Dhar R K, Basu K and Saha K C, 1998. Calcutta's Industrial pollution: Ground water arsenic contamination in residual area sufferings of people due to industrial effluent discharge- An eight year study report. Curr. Sci. 74: 346-355

Chaudhary Suman June 18, 2003, News Report: Times of India

Chaudhary K, Ehmann W D, Rengan K and Markesbery W R, 1995. Trace element correlation with age and sex in human Fingernails. Journal of Radioanalytical and Nuclear Chemistry, 195 (1): 51-56

Chen K L, Amarasiriwardena C J and Christiani D C, 1999. Determination of total arsenic concentrations in nails by inductively coupled plasma mass spectrometry. Biol Trace Elm Res, 67 (2): 109-25.

Cumming and Kay,1956. Quantitative chemical analysis revised by Robert Alaxander, Chalmers, London, 111$112,124-125,332-334$

D'I 1 i o S, Violante N and Senefonte O, 2000. Occupational exposure of goldsmith workers of the area of Rome to potentially toxic metals as monitored through hair analysis. Microchemical Journal, 67: 343-349

Das D, Chatterjee A, Mandal B K, Samanta G, Chakraborti D and Chanda B, 1995. Arsenic in ground water in six districts of West Bengal, India: the biggest arsenic calamity in the world. Part 2. Arsenic concentration in drinking water, hair, nails, urine, skin-scale and liver 
tissue (biopsy) of the affected people. Analyst, 120 (3): 917-24

Dombovári J and Papp L, 1998. Comparison of sample preparation methods for elemental analysis of human hair. Microchemical Journal, 59: 187-193

Dombovári J, Papp L and Uzonyi I, 1999. Study of crosssectional and longitudinal distribution of some major and minor elements in the hair samples of haemodialysed patients with micro-PIXE. Journal of Analytical Atomic Spectrometry, 14: 553-557

Egeland G M, Ponce R, Knecht R, Bloom N S, Fair J and Middaugh J P, 1999. Trace metals in ancient hair from the Karluk Archaeological Site, Kodiak, Alaska. Int J Circumpolar Health. 58 (1): 52-6

Harrison W W and Tyree A B, 1971. The determination of trace elements in human fingernails by atomic absorption sprectroscopy. Clin Chim Acta, 31: 63-73

Hira C K, Partal K and Dhillon K S, 2004. Dietary selenium intake by men and women in high and low selenium areas of Punjab. Public Health Nutr, 7 (1): 39-43

Kaluza J, Jeruszka M and Brzozowska, 2001. Iron, zinc and copper status of elderly people living in Warsaw district determined by hair analysis. Roczniki Pañstwowego Zak adu Higieny, 52 :111-118

Nowak B, 1993. Levels of heavy metals in biological tests (hair, teeth) as an indicator of environmental pollution, International conference - heavy metals in environment, Toronto, 2: 408-411
Schlegel-Zawadzka M, 1992. Chromium content in the hair of children and students in southern Poland. Bio Trace Elem Res, $32: 79-84$

Snell F D and Snell C T, 1967. The colorimetric methods of analysis including photometer method. D. Van. Nostrand company Inc.Princton, NewJersey, Toronto, London, 4 $2173: 437-438$

Steinmaus C M, Nuñez S and Smith A H, 2000. Diet and bladder cancer: a meta-analysis of six dietary variables. Am J Epidemiol, 151 (7) : 693-702

Subramanian R and Sukumar A, 1988. Biological reference materials and analysis of toxic elements. Fresenius' Zeitschrift für analytische Chemie, 332 (6) :623-626

Suhonen R P R and Dawber D H, 1999. Fungal infection of the skin, hair and nails, Martin Dunitz, London.

Wang C Y, Zhou Y M and Yang W Z, 1995. Multielement ICP-AES analysis of hair samples and a chemometrics study for cancer diagnosis. Microchemical Journal, 51 : 5-14

WHO 1994. Environmental Health Criteria 160: $2^{\text {nd }}$ Edition, Report of International Programme on Chemical Safety

Wilhelm M, Lombeck I and Ohnesorge F K,, 1994. Copper, lead and zinc concentrations in hair and toenails of young children and family members: a follow-up study. Sci Total Environ, 141(1-3) :275-80

Zhunk L I and Kist A A, 1995. Human hair instrumental neutron activation analysis and medicine. Journal of Radio analytical and Nuclear Chemistry, 195: 75-81 